\title{
China's Climate Change Policy Strengthening Its Diplomacy
}

\section{Ica Wulansari}

International Relations Department, University of Paramadina

Jenderal Gatot Subroto Street, Jakarta 12790

ica.wulansari3@gmail.com

Submitted: 11 May 2015, Accepted: 12 September 2015

\begin{abstract}
Abstrak
Tulisan ini bermaksud meneliti diplomasi Tiongkok dalam kerangka perubahan iklim. Tulisan ini juga akan meneliti bagaimana Tiongkok menitikberatkan kepentingannya yang sejalan dengan efek laju perubahan iklim. Tiongkok seharusnya mempertimbangkan perubahan iklim sebagai ancaman bagi kepentingan nasional karena hal tersebut berimplikasi pada pertumbuhan ekonominya. Saat ini, Tiongkok menggunakan bahan bakar fosil yang menghasilkan emisi karbon dioksida yang tinggi. Sebagai respon, Tiongkok menekankan kebijakan energi untuk mengurangi emisi melalui The National Development and Reform Commission (NDRC), yang bertugas untuk memastikan standardisasi mitigasi dan adopsi pada kebijakan perubahan iklim. Tiongkok juga telah membuat kebijakan dengan menekankan tanggungjawab pada produksi emisi historis negara-negara maju dan hak untuk emisi pada negara-negara berkembang. Di level internasional, Tiongkok memiliki peran strategis dalam Conference of Parties (CoP) di UNFCC (United Nations Framework Convention on Climate Change). Di samping itu, Tiongkok juga memperdalam kerjasama dengan Amerika Serikat dalam perubahan iklim.

Kata kunci: Tiongkok, perubahan iklim, kebijakan, diplomasi.
\end{abstract}

\begin{abstract}
This research attempts to examine China's climate change diplomacy. This paper also observes how China strengthens its interest in line with the speed of climate change impact. China should consider climate change as the threat for its national interest since it impacted to its rapid economic growth. Currently, China's use of fossil fuel has produced the significant amount of carbon dioxide emissions. In response to this, China considered to strengthen its energy policy as a way to reduce emission through The National Development and Reform Commission (NDRC) whose job is to confirm that mitigation and adoption of climate change are standardized. Furthermore, China has issued the principle of equity in 2009 by strengthening the responsibility for historical emissions of the developed countries and the future emissions rights of the developing countries. At the international level, China played a strategic and significant role in Conference of Parties in UNFCC (United Nations Framework Convention on Climate Change). In addition, deepening a climate change cooperation with the United States was also at China's lists.

Keywords: China, Climate Change, Policy, Diplomacy
\end{abstract}

\section{INTRODUCTION}

China changed its development strategies as worldwide factory producer. That is why China has potentially huge markets and increases its economic growth very rapidly. Paul G. Harris on his book "World Ethics and Climate Change from International to Global Justice" stated that in 2006 China overtook the United States to become the largest national source of greenhouse gas emissions (Netherlands Environmental Assessment Agency 2008). The Chinese Academy of Sciences predicts that, without dramatic changes in business as usual, by 2030 . China`s greenhouse gases (GHG) emissions will more than double, rising from about 5.1 billion tonnes of carbon in 2005 to as much as 14.7 billion tonnes and in 2007, China produced 31.2 tonnes for the entire world (Harris, 2010:126). Meanwhile, China`s population reached 1.3 billion people and its economy is one of the world largest and fastest growing (Hongyuan, 2008:47). China was producing over 6,000 megatonnes of carbon dioxide (CO2) on a 
yearly basis, it is the world's largest emitter of GHG (Held et al, 2011:6).

As an emerging world factory's owner, China needs more energy for its industries. Twenty years ago, China was an East Asia's largest oil exporter. Indeed, China's coal-fired power sector is the world's largest anthropogenic source of CO2 emissions, and by 2009 the country's CO2 emissions were 24 percent of the global total, despite China having substantially less than a quarter of the world's population (Harris, 2011:6-7). Highly usage of fossil fuel in China is as consequences as the biggest emitter in the world. China is the number one in the world for annual share of global emissions 24 percent, annual per capital emissions 5.1 tons. The United States was in the second rank for the annual share of global emission 21 percent (Moran, 2011:10). As the biggest emitter in the world, China faces environmental threat very seriously, especially climate change impact. Joanna Lewis mentioned that climate change will threat China (Moran, 2011:11):

- Decreased precipitation. Studies predict that precipitation may decline by as much as 30 in the Huai, Liao, and Hai river regions in the second half of the century. Climate change could decrease river runoff in northern China, where water scarcity is already a problem, and increase it in southern China, where flooding and heavy rains are already a problem.

- Severe weather events. Climate change is expected to increase the frequency and severity of storm surges, droughts and extreme climate events.

- Sea level rise. Estimates sea level rise along China's coastline range between 0.10 and 0.16 meter by 2030, and between 0.4 and 1 meter by 2050 .

- Glacial melt. The effect of climate change on the glaciers on China's Tibetan Plateau will have severe repercussions for the century's lakes and rivers systems.

The rapid economic growth in China has started after the economic reforms were launched in 1978. Since the beginning of the reform era in 1978, when Deng Xiaoping launched the 'open-door policy',
China has experienced an incredible economic growth of up to 10\% annually (Bjørkum, 2005:8-9). Since its economic reform in 1978, China has adopted exportdriven development strategy, following Japan and South Korea's development (Kassiola and Guo, 2010:71). Every country has interest to achieve its targeted economy level. As a developing country, China has transformed to adapt a new pattern for its economy. 'Open door policy' has opened the opportunity for China to maximize its industry and build development strategy with heavy industry. But, at the same time, rapid exploitation of natural resources causes environmental damage. China faces environmental threat seriously, especially on climate chance. Amazing Economic growth makes China powerful in international community. Nowadays, Chinese economic growth is affected by the way how the government deals with climate change issues. The research question is how China design its policies through domestic policy to strengthen the national interest by implementing Chinese's climate change diplomacy.

\section{THEORETICAL FRAMEWORK}

According to Mark. J. Lacy on his book 'Security and Climate Change' pointed to the John J. Mearsheimer's thinking about relationship climate change with realist perspective. "For Mearsheimer an ecological threat such as human-generated climate change would be characterized as (at most) a Second-Order problem: there is very little "evidence" that climate change could threaten a Great Power. With this move Mearsheimer is able to quickly take his discussion away from non-traditional threats to the First-Order concerns of his Realist politics of security" (Lacy, 2005:23). Climate change impact as mentioned by Mearsheimer was a serious threat for Great Power. Lacy identified that Mearsheimer emphasized that dichotomy of First-Order and Second-Order problems that emerges in the conclusion of Mearsheimer's The Tragedy of Great Power Politics.

Mearsheimer's hierarchy of First-Order and SecondOrder problems is created to maintain a secure borderline between military threats and non-traditional threats. Mearsheimer has predicted that First- 
Order goes to The United States and Second-Order goes to China. These two countries will fight for its hegemony. "Mearsheimer's conclusion is that China will become a peer competitor for the United States because if it becomes the leading producer of cutting-edge technologies, it would use the wealth to create a "mighty military machine". In the final pages of The Tragedy of Great Power Politics, Mearsheimer declares that as China could become a formidable superpower it follows that the United States has an interest in making sure that Chinese economic growth very statically" (Lacy, 2005:33).

The classic realist statement on diplomacy and the making of relations is found in Hans Morgenthau's highly influential Politics Among Nations. His starting assumption is that there is anarchy in international politics. Thus, states have to be on guard in order to secure their survival (Bjola\&Kornprobst, 2013:114). One reason why realists seem to ignore or marginalize these significant developments in environmental multilateralism is that they simplify, and therefore misconceive, the relationship between power and morality, and between material interests and ideas/ culture, in world politics (Eckersley, 2004:26). Of course, it cannot be denied that most environmental regimes and negotiations are also based on a good deal of strategic bargaining and haggling over the distribution of benefits and burdens (Eckersley, 2004:32). Multilateralism classifies as a consensus, but in reality it led by Great Power which owns economic power sufficiency. Usually, Great Power uses its force to secure its interest, but on the other hand, the other countries inevitable should unconditionally agree with the agreement. Multilateralism is the Great Power's instrument to achieve international image by maximizing its advantages.

Climate change must also be part of an overall approach to national security and defense planning (Mazo, 2010:141). Climate change is a serious issue that will destroy human security. Climate change have related with all sector of human's life, including water availability, food security, and energy security, besides that climate change impact will decrease human life quality. To cope with that, climate policy with adapta- tion and mitigation policy is needed. Climate policy depends on how diplomacy works. Dennis Tanzler and Alexander Carius on their argument "Overview Towards Preventive Climate Diplomacy" that today, climate change is more than climate negotiations, it is climate-sensitive economic, trade, investment, finance, population and development policy which affects the overall development of nations. Climate diplomacy needs the accompany to output of international climate negotiations, such as adaptation and climate finance, competitiveness, and economic development with a strong foreign policy impetus (Tanzler\& Carius, 2012:9-10).

Jeremy Black on his writing 'Diplomatic History An New Appraisal' mentioned that diplomacy was designed to use force to unsure profit (just as force was the medium to achieve foreign policy goals) it is not unexpected that both standing armies and diplomatic networks emerged at the same period (McKercher, 2012:5). Besides that, Christer Jonsson said that diplomacy sometimes refers to the content of foreign affairs as a whole. Diplomacy considered as foreign policy implementation. It means that theories of foreign policy are applicable. Secondly, diplomacy may connote the conduct of foreign policy. A third connotation of diplomacy focuses on the management of International Relations by negotiation (McKercher, 2012:15).

\section{RESULT AND ANALYSIS}

\section{CHINA CLIMATE CHANGE MITIGATION POLICY}

The Chinese government released its first "National Assessment Report on Climate Change" in 2006. It is a collaborative effort among more than 20 government departments and it took four years to complete. In 2007, China established the National Leading Group to Address Climate Change. The National Climate Change Programme (ying dui qi hou bian qian guo jia fang an) in 2007 is China's first policy document in response to climate change. (Liu and Teh, 2011:370). China took climate change issue seriously to be part of its domestic and foreign policy. China has designed the national strategy to support sustainable develop- 
ment. In 2013, the Chinese government released the National Strategy for Climate Change Adaptation, specifying the guiding thoughts and principles in adapting to climate change on a national level by 2020 . The National Development and Reform Commission (The NDRC) constitutes representative of Chinese government has formulated that China has made significant progress in addressing climate change (NDRC, 2014).

Chinese officials have also recently indicated that the 2020 target for renewable energy could be increased from 15 per cent (NDRC 2007) to 20 per cent (Garnaut et al, 2009:417-418). China has had limited success in achieving its 4 per cent annual reduction goal for energy intensity the goal it would need to continue with for another decade to achieve a halving of its carbon intensity. (Garnaut et al, 2009:420). Climate change in Chinese government's perspective is a serious problem that leads into state instability for all sectors that is why China needs a special ambassador for it. China's former special ambassador for climate change, Yu Qingtai stated that: "climate change is in fact a comprehensive question with scientific, environmental and development implications and involves the security of agriculture and food, water resource, energy, ecology, and public health and economic competitiveness, and if the climate changes dramatically, the survival of mankind and the future of earth might be impacted" (Moran, 2011:11). China's policies on managing climate change are officially guided by six principles (Harris, 2011:8):

- Addressing climate change within the broader framework of the country's national sustainable development strategy;

- Addressing both climate change mitigation and adaptation

- Integrating climate change-related policies with programs for national and social economic development

- Relying on technological advancement for effectively mitigating and adapting to climate change, and

- 'Actively and extensively' participating in international cooperation on climate change
Since 2013, Chinese government has goals and targets mitigating climate change with Twelve Five-Year Plan. The mitigation is applied to support industrial structure, saving energy, increasing energy efficiency, optimizing energy structure, controlling the emission of GHG induced by non-energy activity, and increasing carbon sinks reach the level of reduction of carbon emission as required by the Chinese government. Mitigation of climate change is done through reducing emissions of greenhouse gases, shifting to carbonneutral energy sources such as biofuels or reducing $\mathrm{CO} 2$ concentrations through reforestation. Mitigation and adaptation are for the most part complementary responses to global warming (although sometimes, as in the case of conversion of agricultural or forest land to biofuel production, mitigation efforts can make the impacts worse). (Mazo, 2010:124). The NDRC has made energy efficiency policies focus on renewable energy to support China's climate change programs: enhancing energy-saving assessments and inspections; accelerating the implementation of key energy conservative projects; further improving energy efficiency standard and labeling scheme; promoting energy conservative technologies and products; boosting energy conservation in the construction sector; promoting energy conservation in the field of transportation and energy efficiency (NDRC, 2014). China has systematically made significant efforts in mitigating climate change.

\section{CHINA'S DIPLOMACY IN CLIMATE CHANGE REGIME}

China's diplomacy in climate change has several goals: protect Chinese sovereignty, acquire foreign aid and technical assistance, promote China's economic development, and promote its role as a responsible great power and leader of the developing country and its growing role as a major contributor to global environmental problems (such GHG emissions) to acquire substantial influence in international environmental negotiations (Harris, 2011:9-10). China articulated to secure their national interest to protect its sovereignty by taking advantages for its position in example obtaining aid and technology from developed 
countries. Besides that, China positioned itself as a developing country whenever demonstrating leadership to counter The United States authority in international negotiation. Moreover, China's will build environmentally sustainable development as part of mitigating climate change for long term objective.

China has articulated its national interest in Rio Earth summit in June 1992. Premier Li Peng noted that Greenhouse gases emission were threatening the national security of many countries and regions. There are two kinds of these interests: the first include: international funds and international environment aid projects. The second include the knowledge new interest after joining the international regimes. (Hongyuan, 2008:35). China was one of ratify the United Nations Framework Convention on Climate Change (UNFCCC) in 1993 (Haibin, 2013:1). In 1997, China's climate change policy started when the parties attended UNFCCC (United Nations Framework Convention on Climate Change)

acknowledge the Kyoto Protocol to the present. Chinese diplomacy has focuses two issues: 1) how to accept developed countries international environmental trading mechanism 2) preventing developing countries from being forced to assume concrete responsibilities GHG emissions reduction. China rejected emission trading and Joint Implementation schemes, insisting that these approaches were unacceptable because, consequently, it would make developed countries do not have responsibilities for emissions reduction at home country while disregarding the living environment of people in other countries (Hongyuan, 2008:57). China took a leadership for developing countries with G77+China objected their involvement on Joint Implementation as Kyoto Protocol article 6. China viewed that it will avoid developed countries from their responsible to reducing their emissions.

China's position as developing country has a powerful influence to G-77. G-77 is developing countries coalition that promotes their interests as the representative of developing countries in Asia, Africa, South America, Pacific and Caribbean islands except Cook Islands, Kiribati, Nauru, Niue, Palau and Tuvalu. G-77's agenda are equality, transfer of technology, capacity building and development to support economic growth (Murdiyarso, 2003:17). China's position has been mainly expressed through the "G77 and China" group. China has strengthened its position in climate change international regime by actively participating in G77. G77 is an instrument for China to strengthen its powerful lobby to gain support from developing countries so that China along with developing countries do not have any responsible to reduce the emissions same amount as developed countries according to 'G77 and China' (Bjørkum, 2005:27-28). For G-77 and China, they must prioritize their development to achieve economic and social welfare. If not, they burden same obligation, meanwhile developed countries will always grow but contrast with developing countries that they never achieve economic growth. With G77, China took 'no voluntary commitment' in COP (Conference of Parties-UNFCC).

Chinese government rejects internationally binding limits its on GHG emission as for two very good ethical reasons: the developed countries polluted the atmosphere as they became wealthy, so they ought to reduce their emissions before expecting China to do so; and China is a developing country with millions of poor people, meaning that it should be allowed to raise living standards before being required to limit GHG pollution (Harris, 2011:2). China has shown some contrast conduct apart from rejection to reduce its emission, but on the other hand, China gains a benefit to get funding and technological transfer from CDM (Clean Development Mechanism) program (Hongyuan, 2008:57). China is also receiving environmental technologies, such as those offers in the context of the UNFCCC's Clean Development Mechanism (CDM), which funds climate change related projects in developing countries (Hongyuan, 2008:56). CDM is a mechanism to regulate Annex I and non-Annex I where developed countries and developing countries have different responsibility in reducing carbon emission. The mechanism gives away CDM funding to support sustainable development for 
developing countries (Wulansari, 2010:63). CDM was initiated by developed countries to achieve their binding GHG emissions reduction targets by way of cooperation with developing countries. The core of CDM is to allow developed countries to obtain Certified Emissions Reductions (CERs) from joint projects in cooperation with developing countries. The CDM made it possible for China to lower its abatement costs by introducing more advanced energy technology and partial financing from developed countries (Haibin, 2013:9).

In the UN climate change summit in New York in September 22, 2009, Chinese President Hu Jintao further announced ambitious national climate-change plans. Hu pledged to cut $\mathrm{CO} 2$ emissions per unit of GDP by a notable margin by 2020 from the 2005 level, reiterated his pledge to make 15 percent of China's energy renewable by 2020 and committed to increase China's national forest coverage by 40 million hectares by 2020 (Kassiola and Guo, 2010:63). Hu points out that states should join hands in facing the common threat of climate change and China has set national plans in response. China will further integrate actions on climate change into its economic and social development plan and take strong measures to reduce carbon emission (Liu and Teh, 2011:371).

Under Xi Jinping, China seems likely to continue to play a role jointly with others actors in fighting global warming and climate change. In July 2013, China hosted the eco-global forum in Guiyang city, an annual event with strong support from the Chinese government (Yongnian and Gore 2015, 326). China actively bargained to strengthen its position in international climate change negotiation to build an image that China has a political will to reduce their emission. In September 2014, Vice Premier of the State Council Zhang Gaoli, as the Special Envoy of President Xi Jinping, attended The United Nations Climate Summit and delivered a speech, which had extensive influence on the international society. Zhang Gaoli stressed that China attaches great importance to tackling climate change and is willing to work with the international community to actively tackle the grave challenge of climate change (Lewis, 2014). China addressed climate change issue by reducing carbon intensity, increasing the proportion of non-fossil energy in energy consumption, increasing its forested area. Those are efforts by China before signing new climate treaty in Paris Climate Change Conference in 2015.

\section{CHINA AND THE U.S. CLIMATE CHANGE COOPERATION}

The United States rejected Kyoto Protocol for it is dissident mechanism reduce greenhouse gas in 2001. The U.S. position of Kyoto Protocol depends on its domestic politics. There are different argument between Democrat and Republic party in congress which influenced by business sector including oil industry that powerful lobby in The U.S government. President Bush emphasizes the rejection of Kyoto Protocol (Murdiyarso, 2003: 26-27):

- Eighty per-cent of world citizen (including China and India) are free from responsibility to reduce their emission.

- Kyoto protocol implementation has negative impact to U.S.'s economic growth that require the usage of energy replacing coal to gas which is more expensive.

- Kyoto Protocol is an unfair and effectiveness mechanism in global climate change.

- Based on The U.S. Clean Air Act, CO2 is excluded from emitter while Kyoto protocol claims that $\mathrm{CO} 2$ is one of emitter.

- Scientific truth about Climate change and how to cope with is still questionable for The United States administration.

The common national interest for both China and U.S. has created them to build cooperation to mitigate and manage climate change. The U.S. and China have played their role in Conference of Parties in Copenhagen. Both countries initiated and strengthened their negotiation. The bilateral agreements started in 2009 where China and The U.S. have the same need to mitigate their energy. China and The U.S. are the world's top two GHG emitters, therefore, any solution to the challenge of global climate change 
will require both countries to transition to low carbon economies based on much wider use of 'clean' energy technologies. (Cohen, 2009:19).

Joanna Lewis on her article titled "The State of USChina Relations on Climate Change: Examining the Bilateral and Multilateral Relationship" said that in 2009, Memorandum of Understanding to Enhance Cooperation on Climate Change, Energy and the Environment has engaged China and the U.S. The U.S. Department of Energy and The NDRC have fully participated in this agreement. This cooperation targeted for ten year Energy and Environment Cooperation Framework which strengthen their planning for mitigating climate change to energy efficiency with implementation of low carbon to support economic growth.

China's effort strengthening communication and cooperation with developing countries to achieve their common interest. Leaders of China and The U.S. have attached great importance to climate change and reached a consensus on strengthening climate change talks and cooperation as well as phase down of hydroclorofluorocarbons (HFCs) during two meetings in 2013 (NDRC, 2014). At the bilateral level, China and The U.S. announced in April 2013 to build climate change working group within framework of the existing strategic and economic dialogue to advance bilateral cooperation on technology, research, conservation and alternatives and renewable energy.

President Xi Jinping and President Barack Obama announced their cooperation in June 2013 that China and The U.S. have agreed to work together and with other countries through multilateral to gradually reduce the production and consumption of HFCs, a key contributor to global warming (Yongnian and Gore, 2015:327-328). As a part of a climate agreement with The U.S., President Xi Jinping of China announced a plan which his country's carbon dioxide emissions would peak "around 2030." President Obama pledged that The U.S. would cut emissions by at least 26 percent from 2005 levels by 2025

(NYtimes, 2014).

China played strategic role with the great power before the final agreement Post Kyoto Protocol. This cooperation is strategic bargaining power to force the consensus as the beginning of new climate change regime. China and The U.S. will play their strategic position to lead their interest in a safe position. During climate change regime after Protocol Kyoto being implemented, there are some objections and rejections related with the obligation to reduce emission from participating countries. This cooperation will give powerful lobby and influence at The UNFCCC meeting in Paris. Next meeting in Paris will determine the future of climate change mitigation global. China, as usually, played safe with its position as developing country and leading G-77. But, on the other hand, China as the biggest emitter should aware to responsible in reducing its emission. Rationally, this cooperation advantageous for their economic interest. Some obligations in climate change regime will be costly such as for shifting energy usage and eco technology but the other side, it is more environmentally friendly.

\section{CONCLUSION}

Today, China has a great potential as a superpower country for its massive trade and investment deals with some countries. China's rise in global economic increasingly gross domestic product (GDP). On the other hand, China defines its performance in international forum by protecting its national interest. As a developing country, China showed the domination to convey its aspiration in international forum. China realized that climate change would harm its economic stability. China addressed climate change within the broader framework of national sustainable development and addressing both climate change mitigation and adaptation. China's commitment to reduce its carbon emissions per unit of GDP by $40-45$ percent started from 2005 to 2020. China's policies on managing climate change are officially guided by The NDRC.

In COP UNFCCC, China consistently positions itself as a developing country then it consequently has no moral obligation to reduce emission. China has 
actively built coalition with G-77 to prosecute developed countries to reduce their emissions as their obligation known as 'differentiated responsibilities'. In 2009, Chinese President Hu Jintao administration, declared to reduce its emission. It shows that China has compromised to participate in COP UNFCCC to reduce emission voluntarily. On the other side, China, as a biggest emitter country, has fully responsibility to cope with it. China has a dynamic diplomacy in global regime. China needs a new international image to facilitate its economic interest in energy sector. China 's domestic policies has change, it is exhibited by renewable energy implementation. Xi Jinping has continued Jintao`s commitment to push China as wind power energy leading country in the world for the future.

Post Kyoto Protocol will be over in the end of 2015. China has played a strategic role on the right time so that China would be well prepared in participating to formulate international agreement Post Kyoto Protocol that will lead to its advantages. In earlier COP UNFCCC, China's image as hard-liner with 'no voluntary' principle. But after Copenhagen talks, China shows an eagerness to participate and to cooperate to reduce their emission. Besides that, China has maintained strategic relationship with The U.S. With their similar 'biggest emitter in the world' label, China and The U.S. strengthen their cooperation as strategy to get their advantages to make their interest will be saved. COP in Paris will determine agreements to cope climate change threats. So then, China and The U.S. are powerful coalition to decisive mitigation and adaptation in climate change that will determine the agreements to replace the Kyoto Protocol.

\section{REFERENCES}

Bjola, Corneliu and Markus Kornprobst. 2013. Understanding International Diplomacy. Theory, Practice and Ethics. New York: Routledge.

Cohen, William S. and Maurice R. Greenberg (commission cochairs). 2009. Smart Power in US-China Relations. A Report of the CSIS Commission on China. Washington: Center of Strategic and International Studies.

Eckersley, Robyn. 2004. The Green State. Rethinking Democracy and Sovereignity. London: The MIT Press.
Fook, Lye Liang. 2015. China and Global Governance New Emphasis amidst a Cautious Approach China and Global Governance. In Zheng Yongnian and Lance L.P. Gore (edited by). 2015. China Policy Series. China Entering the Xi Jinping Era. 2015. New York: Routledge.

Garnaut, Ross; Frank Jotzo and Stephen Howes. 2008. China's rapid emissions growth and global climate change policy. In Ligang Song and Wing Thye Woo (eds) 2008. China's Dilemma economic Growth, The Environment, and Climate Change. China: ANU Epress, Asia Pacific Press, Brooking s Institutions Press and Social Sciences Academic Press.

Harris, Paul G. 2010. World Ethics and Climate Change From International to Global Justice. Great Britain: Edinburg University Press.

Harris, Paul G. (edited by). 2011. China's Responsibility For Climate Change. Ethics, Fairness and Environmental Policy. Great Britain: The policy Press. Great Britain. Hongyuan, Yu. 2008. Global Warming and China's Environmental Diplomacy. New York: Nova Science Publisher.

Howes, Stephen. 2009. Can China rescue the global climate change negotiations? In Ross Garnaut, Ligang Song and Wing Thye Woo (eds). 2009. China's New Place In A world In Crisis, Economic, geopolitical and Environmental Dimensions. Canberra: ANU E Press( The Australian National University ( Canberra.

Lacy, Mark J. 2005. Security and Climate Change. New York: Routledge.

Lewis, Joanna. 2011. China. In Daniel Moran (editor). 2011. Climate Change and National Security. A Country Level Analysis. Washington: Georgetown University Press.

Liang, Wei. 2010. Changing Climate? China's New Interest in Global Climate Change Negotiations. in Joey Jay Kassiola and Sujian Guo (edited by). 2010. China's Environmental Crisis, Domestic and Global Political Impacts and Responses. New York: Palgrave Macmillan.

Mazo, Jeffrey. 2010. Climate Conflict. How Global Warming Threatens Security and What to do About It. New York: Routledge.

McKercher (edited by). 2012. Routledge Handbook of Diplomacy and Statecraft. New York: Routledge.

Murdiyarso, Daniel. 2003. Protokol Kyoto Implikasinya bagi Negara Berkembang. Jakarta: Kompas.

Tanzler, Dennis and Alexancer Carius (eds). 2012. Climate Diplomacy in Perspective From Early Warning to Early Action. Berlin: Berliner Wissenschafts-Verlag.

\section{DOCUMENTS}

Bjørkum, Ida. 2005. China in The International Politics of Climate Change. A Foreign Policy Analysis. FNI Report 12/2005. Norway: The Fridtjof Nansen Institute. Lysaker.

China's Policies and Actions on Climate Change. 2014. The National Development and Reforms Comission (NDRC).

JOURNAL

Liu, Ting and Tony Tai. 2011. China's Response to Climate Change: A Policy Analysis. Journal of Alternative Perspectives in the Social Sciences Vol 3, No 2, 362-375, 2011. Taiwan: National Chung Hsing University and National Chung Hsing University. 
Wulansari, Ica. 2010. Deforestasi Di Indonesia dan Mekanisme REDD. Jurnal Ilmiah Hubungan Internasional. Volume 6 Nomor 2,

September 2010. Indonesia: Parahyangan Catholic University.

\section{WORKING PAPER}

Haibin, Zhang. 2013. China and International Climate Change Negotiations. http://welttrends.de/res/uploads/Zhang_China-andInternational-climate-change-negotiations.pdf.

Held, David; Eva-Maria Nag and Charles Roger. 2011. The Governance of Climate Change in China. LSE, Global Governance, and Agence Francaise Developpement. http://www.lse.ac.uk/ globalGovernance/publications/workingPapers/ climateChangelnChina.pdf

\section{WEBSITE}

Joanna Lewis. 2008. China's Strategic Priorities In International Climate Change Negotiations. http://www.c2es.org/newsroom/ articles/chinas-strategic-priorities-international-climate-changenegotiations

Joanna Lewis. Feature Article. The State of US-China Relations on Climate Change: Examining the Bilateral and Multilateral Relationship. http://www.wilsoncenter.org/sites/default/files/ Feature\%20Article\%20The\%20State\%20of\%20U.S.China\%20Relations\%20on\%20Climate\%20Change.pdf-JW

World Resources Institute (WRI)-Issue brief- Opportunities To Reduce Water Use And Greenhouse Gas Emissions in The Chinese Power Sector. http://www.wri.org/sites/default/files/ghg-chinese-powersector-issuebrief_1.pdf

http://www.theguardian.com/environment/2014/nov/12/china-and-usmake-carbon-pledge

http://www.nytimes.com/2014/11/13/world/asia/climate-change-chinaxi-jinping-obama-apec.html?_r=0

http://wri.org/blog/2015/04/china's-climate-action-well-underway http://www.nytimes.com/2009/09/23/world/asia/23hu.text.html?_r=0 